\title{
African hydrogeology and rural water supply
}

\author{
Alan M. MACDONALD ${ }^{1}$, Jeff DAVIES ${ }^{2}$ \& Roger C. CALOW ${ }^{2}$
}

${ }^{1}$ British Geological Survey, West Mains Rd, Edinburgh, EH9 3LA, UK, tel +44 131650 0389, amm@bgs.ac.uk

${ }^{2}$ British Geological Survey, MacLean Building, Wallingford, Oxfordshire, OX10 8BB, UK.

\begin{abstract}
The widespread development of groundwater is the only affordable and sustainable way of improving access to clean water and meeting the Millennium Development Goals for water supply by 2015. Current approaches to rural water supply, in particular demand driven approaches and decentralisation of service delivery have many benefits to the overall efficacy and sustainability of water supplies, however, problems arise when projects do not take into consideration the nature of the groundwater resources. Different approaches and technologies are required depending on the hydrogeological environment. Sub-Saharan Africa (SSA) can be divided into four hydrogeological provinces: (1) The crystalline basement occupies $40 \%$ of the land area of SSA and supports 235 million rural inhabitants. (2) Volcanic rocks occupy $6 \%$ of the land area of SSA, and sustain a rural population of 45 million, many of whom live in the drought stricken areas of the Horn of Africa; (3) Consolidated sedimentary rocks occupy 32\% of the land area of SSA and sustain a rural population of 110 million: (4) Unconsolidated sediments occupy 22\% of the land area of SSA and sustain a rural population of 60 million. Hydrogeological expertise can have significant benefit to rural water supplies by increasing capacity throughout projects by effectively transferring knowledge; by providing authoritative benchmarking, by focused research and by providing accessible advice to planners and policy makers
\end{abstract}

Running title: African hydrogeology and water supply

Word Count: 7800 


\section{Introduction}

At least $44 \%$ of the population in sub-Saharan Africa (some 320 million people) do not have access to clean reliable water supplies (JMP, 2004). The majority of those without access (approx 85\%) live in rural areas where the consequent poverty and ill health disproportionately affect women and children (DFID, 2001; JMP, 2004). In response, the international community has set the Millennium Development Goals (MDGs) which commit the UN membership to reduce by half the proportion of people who are unable to reach, or afford, safe drinking water by the year 2015 (United Nations, 2000). Poverty reduction and sustainable development are now given highest priority.

In this context, the need for sustainable development and management of groundwater cannot be overstated. Across large swathes of Africa, South America and Asia, groundwater provides the only realistic water supply option for meeting dispersed rural demand - alternative water resources can be unreliable and expensive to develop (Foster et al., 2000; MacDonald et al., 2005).

Yet many projects spend large amounts of money installing water sources without trying to understand the groundwater resources on which these sources depend. As a result, many supplies are unsuccessful or perform poorly (Robins et al., 2006). Successfully developing groundwater resources sustainably and cost-effectively on the scale required to help achieve the Millennium Development Goals is not trivial. The challenge is more than just providing extra drilling rigs to the worst-affected countries: technology, software and hardware must all be appropriate to the nature of the groundwater resources in the project area.

In this paper we discuss the groundwater resources in sub-Saharan Africa (SSA) in the context of rural water supply: finding and developing groundwater resources to sustain community hand pumps. An extended reference list is given to help follow up technical aspects of the hydrogeology of Africa, which are not discussed in detail here.

\section{Groundwater resources in sub-Saharan Africa}

The availability of groundwater resources in sub-Saharan Africa depends critically on the geology, the history of weathering faulting, and the recharge to groundwater. 
Figure 1 shows the average annual rainfall across sub-Saharan Africa based on data from New \& Hulme (1997). This clearly demonstrates the arid areas, where groundwater recharge is limited and erratic. However, there is no simple direct relationship between average annual rainfall and recharge, and significant recharge $(10-50 \mathrm{~mm})$ can occur where annual rainfall is less than 500 mm (Edmunds \& Gaye, 1994; Butterworth, 1999; Edmunds et al., 2002). Climate change will significantly alter patterns of rainfall and recharge across Africa. Climate models predict that the number of drought episodes in Africa will increase, particularly in Sahel areas, and the number of people affected by sever drought will grow (Hulme et al., 2001; Magrath \& Simms, 2007). Rural water supply, however, does not require large quantities of recharge, and a simple mass balance indicates that recharge of 10 mm per annum would support community boreholes $\left(5 \mathrm{~m}^{3} / \mathrm{d}\right.$ or $\left.0.17 \mathrm{l} / \mathrm{s}\right)$ with hand pumps at a spacing of $500 \mathrm{~m}$ across Africa.

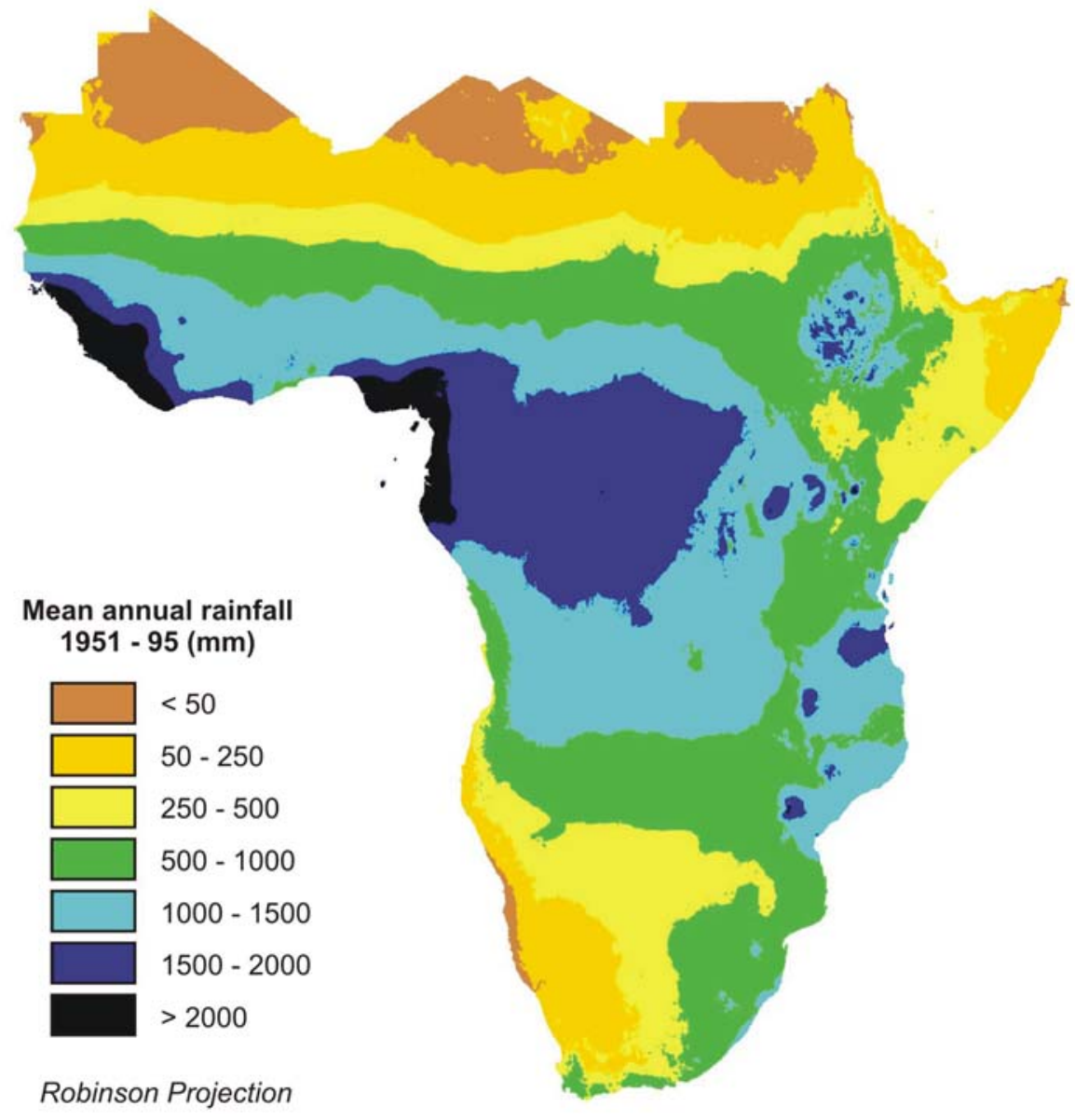

Figure 1 Average annual rainfall for sub-Saharan Africa for the period 1951 1995. Produced from data from New \& Hulme (1997). 
A simplified hydrogeological map is shown in Figure 1 based on a synthesis of studies (Foster 1984; Guiraud 1988; UNTCD 1988; UNTCD 1989; MacDonald \& Davies 2000) and using the 1:5,000,000 scale geological map of Africa as a base (UNESCO, 1991; Persits et al., 1997). The classifications reflect the different manner in which groundwater occurs, constrained by the geological information available at this scale throughout SSA. The four different environments are: Precambrian "basement” rocks; volcanic rocks; unconsolidated sediments; and consolidated sedimentary rocks. Basement rocks form the largest hydrogeological environment, occupying $40 \%$ of the 23.6 million square kilometres and volcanic rocks are the smallest hydrogeological environment with only $6 \%$ of the land area (see Table 1). This basic division forms the basis for the rest of this paper.

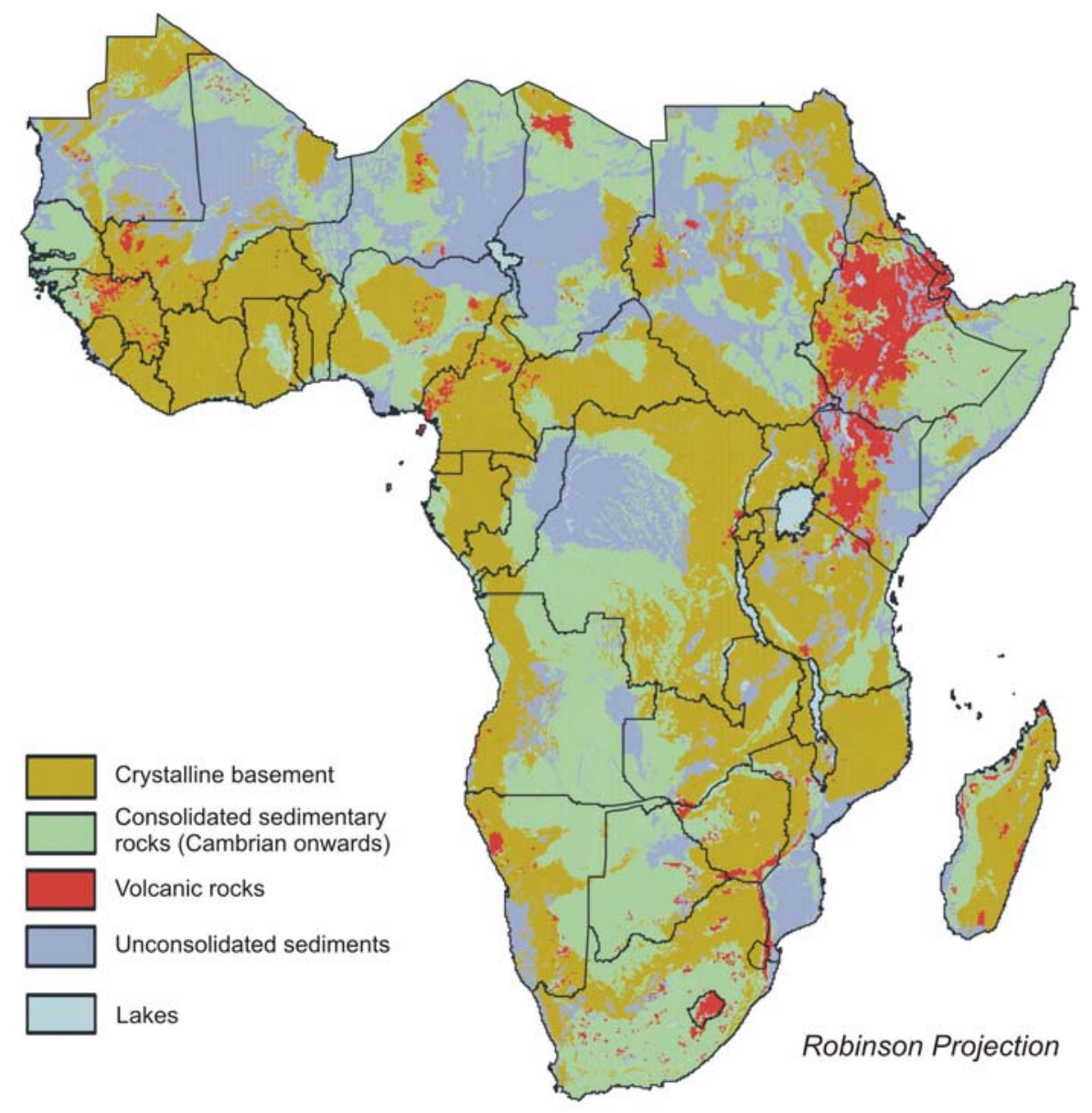

Figure 2 The hydrogeological environments of sub-Saharan Africa (from MacDonald \& Davies, 2000, MacDonald et al., 2005). 
The potential of each hydrogeological environment to contribute to rural water supply is best indicated by the rural population living in each one. As discussed above, the rural communities are most dependent on local resources for water supply, since transportation is often prohibitively expensive and difficult to manage. Using spatial data from ESRI (ESRI, 1996) and statistics from the World Bank and the WHO/UNICEF Joint Monitoring Programme (JMP, 2004), an approximation was made of the distribution of rural population throughout sub-Saharan Africa. The results are shown in Table 1. Basement rocks support the largest population (235 million) and volcanic rocks the least (45 million). However, despite, the relatively low number of people living in hydrogeological volcanic areas, they are particularly important since they are home to some of the poorest and most drought prone people in Africa.

Table 1 The land area of each hydrogeological environment shown in Figure 2, and and estimate of the rural population living on each (ESRI, 1996; World Bank, 2000; JMP, 2004)

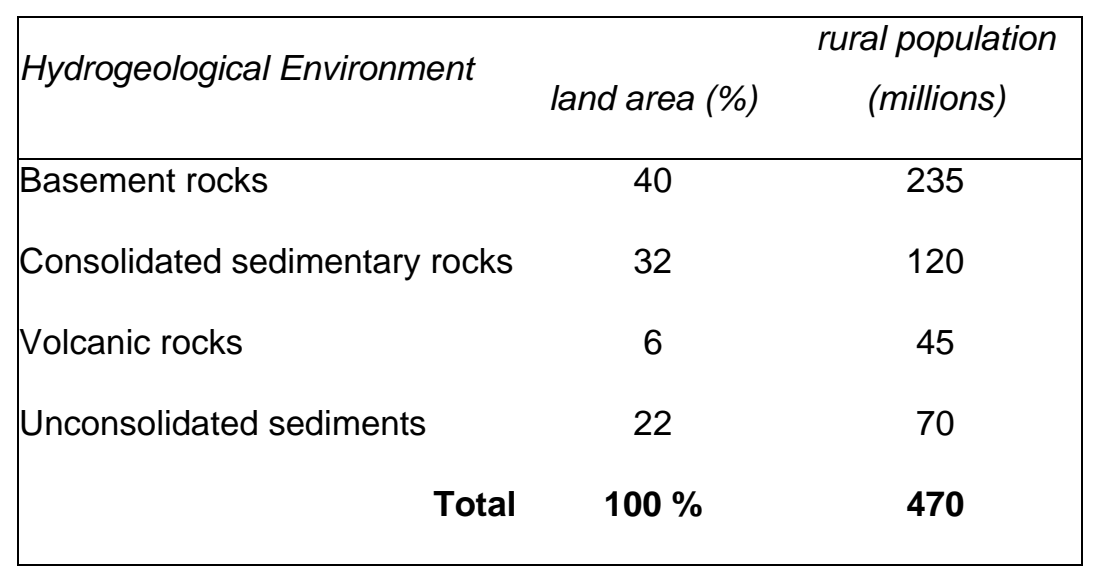

\section{Hydrogeological environments}

In this section each of the hydrogeological environments are described with references to key publications on each. Table 2 provides a summary the groundwater potential for each environment.

Before discussing each hydrogeological environment it is important to define what constitutes an aquifer in the context of rural water supply. If we assume that a borehole is to supply a minimum of $5 \mathrm{~m}^{3} / \mathrm{d}$ to be successful, and that recharge is not a constraint (see above), then the minimum aquifer properties can be estimated that would give a successful source. Modelling 
indicates that transmissivity is the key limiting factor and that generally transmissivity $>1 \mathrm{~m}^{2} / \mathrm{d}$ will give a successful borehole (MacDonald et al., 2008).

Table 2 A summary of the groundwater potential of the African hydrogeological environments (modified from MacDonald et al., 2005).

\begin{tabular}{|c|c|c|c|}
\hline & $\begin{array}{l}\text { Hydrogeologica } \\
\text { I Sub- } \\
\text { Environment }\end{array}$ & $\begin{array}{l}\text { GW potential \& average } \\
\text { yields }\end{array}$ & Groundwater Targets \\
\hline \multirow{2}{*}{ 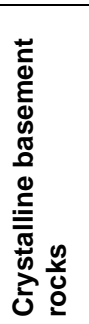 } & $\begin{array}{l}\text { Highly } \\
\text { weathered } \\
\text { and/or fractured } \\
\text { basement }\end{array}$ & $\begin{array}{l}\text { Moderate } \\
0.1-1 \mathrm{l} / \mathrm{s}\end{array}$ & $\begin{array}{l}\text { Fractures at the base of the deep weathered zone. } \\
\text { Sub -vertical fracture zones. }\end{array}$ \\
\hline & $\begin{array}{l}\text { Poorly } \\
\text { weathered or } \\
\text { sparsely } \\
\text { fractured } \\
\text { basement }\end{array}$ & $\begin{array}{l}\text { Low } \\
0.1 \mathrm{l} / \mathrm{s}-1 / \mathrm{s}\end{array}$ & $\begin{array}{l}\text { Widely spaced fractures and localised pockets of deep } \\
\text { weathering. }\end{array}$ \\
\hline \multirow{4}{*}{ 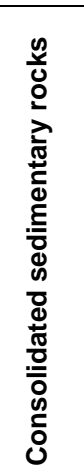 } & Sandstone & $\begin{array}{l}\text { Moderate }- \text { High } \\
1-20 \mathrm{l} / \mathrm{s}\end{array}$ & Coarse porous or fractured sandstone. \\
\hline & $\begin{array}{l}\text { Mudstone and } \\
\text { shale }\end{array}$ & $\begin{array}{l}\text { Low } \\
0-0.5 \mathrm{l} / \mathrm{s}\end{array}$ & $\begin{array}{l}\text { Hard fractured mudstones } \\
\text { Igneous intrusions or thin limestone / sandstone layers. }\end{array}$ \\
\hline & Limestones & $\begin{array}{l}\text { Moderate - high } \\
1-100 \mathrm{l} / \mathrm{s}\end{array}$ & Fractures and solution enhanced fractures (dry valleys) \\
\hline & $\begin{array}{l}\text { Recent Coastal } \\
\text { and Calcareous } \\
\text { Island } \\
\text { formations }\end{array}$ & $\begin{array}{l}\text { High } \\
10-100 \mathrm{l} / \mathrm{s}\end{array}$ & $\begin{array}{l}\text { Proximity of saline water limits depth of boreholes or galleries. } \\
\text { High permeability results in water table being only slightly } \\
\text { above sea level }\end{array}$ \\
\hline \multirow{4}{*}{ 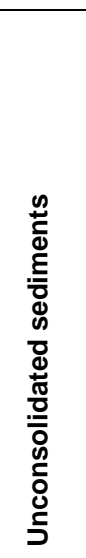 } & $\begin{array}{l}\text { Major alluvial } \\
\text { and coastal } \\
\text { basins }\end{array}$ & $\begin{array}{l}\text { High } \\
1-40 \mathrm{l} / \mathrm{s}\end{array}$ & Sand and gravel layers \\
\hline & $\begin{array}{l}\text { Small dispersed } \\
\text { deposits, such } \\
\text { as river valley } \\
\text { alluvium and } \\
\text { coastal dunes } \\
\text { deposits. }\end{array}$ & $\begin{array}{l}\text { Moderate } \\
1-20 \mathrm{l} / \mathrm{s}\end{array}$ & $\begin{array}{l}\text { Thicker, well-sorted sandy/gravel deposits. } \\
\text { Coastal aquifers need to be managed to control saline } \\
\text { intrusion. }\end{array}$ \\
\hline & Loess & $\begin{array}{l}\text { Low - Moderate } \\
0.1-1 \mathrm{l} / \mathrm{s}\end{array}$ & $\begin{array}{l}\text { Areas where the loess is thick and saturated, or drains down } \\
\text { to a more permeable receiving bed }\end{array}$ \\
\hline & $\begin{array}{l}\text { Valley deposits } \\
\text { in mountain } \\
\text { areas }\end{array}$ & $\begin{array}{l}\text { Moderate - High } \\
1-10 \mathrm{l} / \mathrm{s}\end{array}$ & $\begin{array}{l}\text { Stable areas of sand and gravel; river-reworked volcanic } \\
\text { rocks; blocky lava flows }\end{array}$ \\
\hline 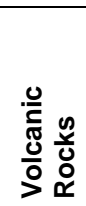 & $\begin{array}{l}\text { Extensive volcanic } \\
\text { terrains }\end{array}$ & $\begin{array}{l}\text { Low - High } \\
\text { Lavas } 0.1-100 \mathrm{l} / \mathrm{s} \\
\text { Ashes and pyroclastic rocks } \\
0.5-5 \mathrm{l} / \mathrm{s}\end{array}$ & $\begin{array}{l}\text { Generally little porosity or permeability within the lava flows, but } \\
\text { the edges and flow tops/bottom can be rubbly and fractured; } \\
\text { flow tubes can also be fractured. } \\
\text { Ashes are generally poorly permeable but have high storage } \\
\text { and can drain water into underlying layers. }\end{array}$ \\
\hline
\end{tabular}

\section{Precambrian basement}

Precambrian basement rocks occupy $40 \%$ of the land area of SSA and support approximately 235 million rural inhabitants. They comprise crystalline igneous and metamorphic rocks over 
550 million years old (Key, 1992). Unweathered and non-fractured basement rocks contain negligible quantities of groundwater. Significant aquifers however, develop within the weathered overburden and fractured bedrock.

The geology of Precambrian Basement areas is complex, reflecting the long history that the environment has been subjected to. Although Precambrian basement terrains largely comprise crystalline igneous and metamorphic rocks, there are also areas of metamorphosed consolidated sediments comprising sandstones, conglomerates, shales and mudstones in west. Two notable examples are the Voltaian Sediments of Ghana and the Transvaal, Waterberg and Ventersdorp Groups in southern Africa.

Five factors contribute to the weathering of basement rocks (Jones 1985; Acworth, 1987):

- tension and stress fractures;

- geomorphology of the terrain; e.g. weathering along fracture controlled valleys, formation of inselbergs

- temperature and occurrence of groundwater controlling the depth and nature of weathering

- mineral content of the basement rock

- the palaeo-climates experienced by the near surface deposits.

The resulting weathered zone can vary in thickness from just a few metres in arid areas to over $90 \mathrm{~m}$ in the humid tropics. Historical erosion surfaces may also be important in preserving ancient weathered surfaces. Figure 3 summarise the permeability and porosity profiles for the weathered zone. Porosity generally decreases with depth; permeability however, has a more complicated relationship, depending on the extent of fracturing and the clay content (Wright \& Burgess, 1992; Chilton \& Foster, 1995). In the soil zone, permeability is usually high, but groundwater does not exist throughout the year and dries out soon after the rains end. Beneath the soil zone, the rock is often highly weathered and clay rich, therefore permeability is low. Towards the base of the weathered zone, near the fresh rock interface, the proportion of clay significantly reduces. This horizon, which consists of fractured rock, is often permeable, allowing water to move freely. Wells or boreholes that penetrate this horizon can usually provide sufficient water to sustain a handpump.

Deeper fractures within the basement rocks are also an important source of groundwater, particularly where the weathered zone is thin or absent. These deep fractures are tectonically 
controlled and can sometimes provide supplies of 1 - 5 l/s. The groundwater resources within the regolith and deeper fracture zones depend on the thickness of the water-bearing zone and the relative depth of the water table. In general terms, the deeper the weathering, the more sustainable the groundwater. However, due to the complex interactions of the various factors affecting weathering (an in particular the presence of clay in the weathered zone), waterbearing horizons may not be present at all at some locations.

Various techniques have been developed to locate favourable sites for the exploitation of groundwater resources within basement rocks. These include remote sensing (Lillesand \& Kiefer, 1994) geophysical methods (Beeson \& Jones, 1988; McNeill, 1991; Carruthers \& Smith, 1992) and geomorphological studies (Taylor \& Howard, 2000). Geophysical surveys using combined resistivity and ground conductivity (EM) surveys have often been found useful in siting wells and boreholes (see Table 3). These can often be successfully interpreted by using simple guidelines, (MacDonald et al., 2005). Although groundwater is generally abstracted th5rough boreholes and wells, more sophisticated systems, such as collector wells have also been used with success, (Ball \& Herbert, 1992; Lovell, 2000).
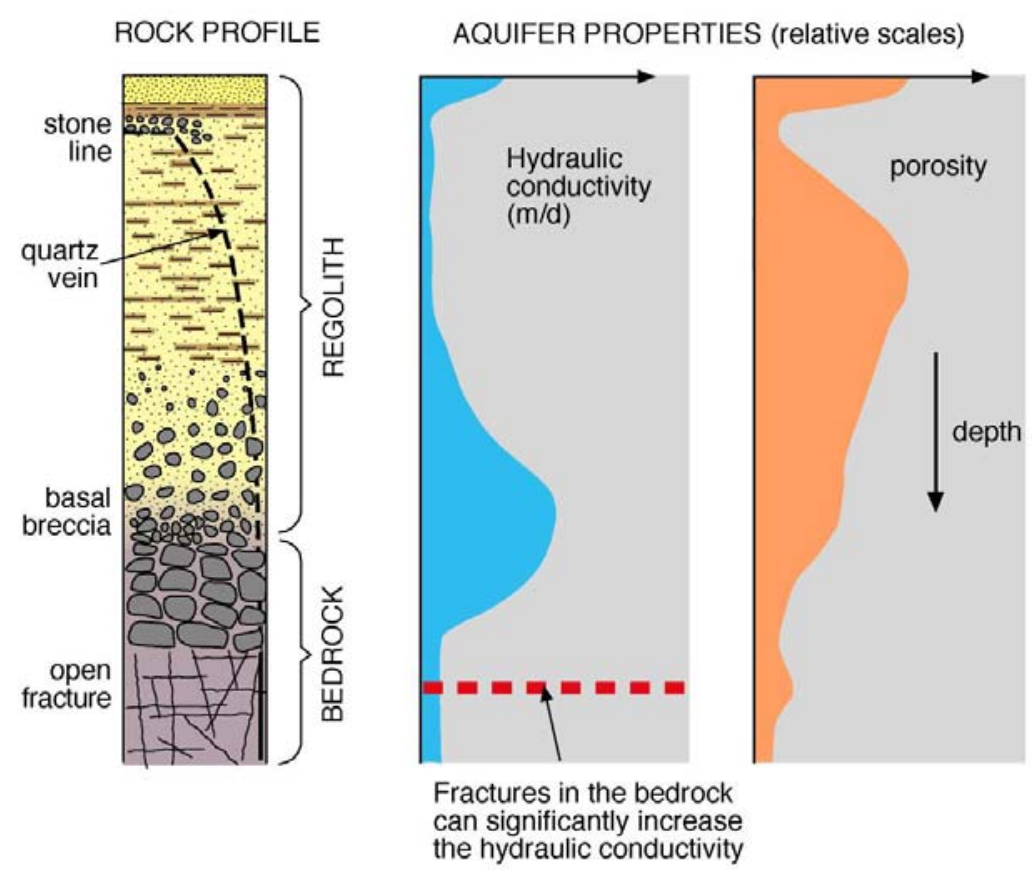
Figure 3 Schematic diagram of the variation of permeability and porosity with depth in the crystalline basement (adapted from Acworth, 1987; Chilton \& Foster, 1995).

\section{Table 3 A summary of common geophysical investigations used in rural water supply projects (see Milsom (2002) for more details).}

\begin{tabular}{|c|c|c|c|c|}
\hline $\begin{array}{l}\text { Geophysic } \\
\text { al } \\
\text { technique }\end{array}$ & What it measures & Output & $\begin{array}{l}\text { Usual } \\
\text { maximum } \\
\text { depth of } \\
\text { penetration }\end{array}$ & Comments \\
\hline Resistivity & $\begin{array}{l}\text { Apparent electrical } \\
\text { resistivity of ground }\end{array}$ & $\begin{array}{l}\text { 1-D vertical } \\
\text { geoelectric section; } \\
\text { more complex } \\
\text { equipment gives 2-D } \\
\text { or 3-D geoelectric } \\
\text { sections }\end{array}$ & $100 \mathrm{~m}$ & $\begin{array}{l}\text { Can locate changes in the thickness and } \\
\text { nature of the weathered zone and differences } \\
\text { in geology. Also useful for identifying } \\
\text { thickness of sand or gravel within superficial } \\
\text { deposits. Often used to calibrate FEM } \\
\text { surveys (see below). Slow survey method } \\
\text { and requires careful interpretation. }\end{array}$ \\
\hline $\begin{array}{l}\text { Frequency } \\
\text { domain } \\
\text { Electro- } \\
\text { Magnetic } \\
\text { methods } \\
\text { (FEM) }\end{array}$ & $\begin{array}{l}\text { Apparent terrain } \\
\text { electrical conductivity } \\
\text { (calculated from the } \\
\text { ratio of secondary to } \\
\text { primary } \\
\text { electromagnetic fields) }\end{array}$ & $\begin{array}{l}\text { Single traverse lines } \\
\text { or } 2 \mathrm{D} \text { contoured } \\
\text { surfaces of bulk } \\
\text { ground conductivity }\end{array}$ & $50 \mathrm{~m}$ & $\begin{array}{l}\text { Quick and easy method for determining } \\
\text { changes in thickness of weathered zones or } \\
\text { alluvium. Interpretation is non-unique and } \\
\text { requires careful geological control. Can also } \\
\text { be used in basement rocks to help identify } \\
\text { fracture zones. }\end{array}$ \\
\hline $\begin{array}{l}\text { Transient } \\
\text { Electro- } \\
\text { Magnetic } \\
\text { methods } \\
\text { (TEM) }\end{array}$ & $\begin{array}{l}\text { Apparent electrical } \\
\text { resistance of ground } \\
\text { (calculated from the } \\
\text { transient decay of } \\
\text { induced secondary } \\
\text { electromagnetic fields) }\end{array}$ & $\begin{array}{l}\text { Output generally } \\
\text { interpreted to give } \\
1 D \text { resistivity } \\
\text { sounding }\end{array}$ & $150 \mathrm{~m}$ & $\begin{array}{l}\text { Better at locating targets through conductive } \\
\text { overburden than FEM, also better depth of } \\
\text { penetration. Expensive and can be difficult to } \\
\text { operate. }\end{array}$ \\
\hline $\begin{array}{l}\text { Very Low } \\
\text { Frequency } \\
\text { (VLF) }\end{array}$ & $\begin{array}{l}\text { Secondary magnetic } \\
\text { fields induced in the } \\
\text { ground by military } \\
\text { communications } \\
\text { transmitters. }\end{array}$ & $\begin{array}{l}\text { Single traverse lines, } \\
\text { or } 2 \mathrm{D} \text { contoured } \\
\text { surfaces. }\end{array}$ & $40 \mathrm{~m}$ & $\begin{array}{l}\text { Can locate vertical fracture zones and dykes } \\
\text { within basement rocks or major aquifers }\end{array}$ \\
\hline $\begin{array}{l}\text { Ground } \\
\text { penetrating } \\
\text { radar (GPR) }\end{array}$ & $\begin{array}{l}\text { Reflections from } \\
\text { boundaries between } \\
\text { bodies of different } \\
\text { dielectric constant }\end{array}$ & $\begin{array}{l}\text { 2D section showing } \\
\text { time for EM waves } \\
\text { to reach reflectors }\end{array}$ & $10 \mathrm{~m}$ & $\begin{array}{l}\text { Accurate method for determining thickness of } \\
\text { sand and gravel. The technique will not } \\
\text { penetrate clay, however, and has a depth of } \\
\text { penetration of about } 10 \mathrm{~m} \text { in saturated sand or } \\
\text { gravel. }\end{array}$ \\
\hline $\begin{array}{l}\text { Seismic } \\
\text { refraction }\end{array}$ & $\begin{array}{l}\text { P-wave velocity } \\
\text { through the ground }\end{array}$ & $\begin{array}{l}\text { 2-D vertical section } \\
\text { of } P \text {-wave velocity }\end{array}$ & $30 \mathrm{~m}$ & $\begin{array}{l}\text { Can locate fracture zones in basement rock } \\
\text { and also thickness of drift deposits. Not } \\
\text { particularly suited to measuring variations in } \\
\text { composition of drift. Fairly slow and difficult to } \\
\text { interpret. }\end{array}$ \\
\hline
\end{tabular}




\begin{tabular}{lllll}
\hline Magnetic & $\begin{array}{l}\text { Intensity (and } \\
\text { sometimes direction) of } \\
\text { earth's magnetic field }\end{array}$ & $\begin{array}{l}\text { Variations in the } \\
\text { earth's magnetic } \\
\text { field either along a } \\
\text { traverse or on a } \\
\text { contoured grid }\end{array}$ & $100 \mathrm{~m}$ & $\begin{array}{l}\text { Can locate magnetic bodies such as dykes or } \\
\text { sills. Susceptible to noise from any metallic } \\
\text { objects or power cables. }\end{array}$ \\
& & \\
\hline
\end{tabular}




\section{Volcanic rocks}

Volcanic rocks occupy only 6\% of the land area of SSA and are found in east and southern Africa where they can form important aquifer systems. In total, about 45 million people are dependent on volcanic rocks for rural groundwater supplies, and they underlie much of the poorest and drought stricken areas of SSA. The groundwater potential of volcanic rocks varies considerably, reflecting the complexity of the geology. There have been few systematic studies of the hydrogeology of volcanic rocks in Africa, although good site studies are given by Aberra (1990), Vernier (1993), Demlie et al. (2007) Kebede et al. (2007). Volcanic rocks are important aquifers in India and have been extensively studied there (e.g. Kulkarni et al., 2000).

The volcanic rocks in SSA were formed during three phases of activity during Cenozoic times, associated with the opening of the East African rift valley and an earlier Late Karoo (Jurassic) phase. These events gave rise to a thick complex sequence of lava flows, sheet basalts and pyroclastic rocks such as agglomerate and ash. Thick basalt lava flows are often interbedded with ash layers and palaeosoils. The potential for groundwater depends largely on the presence of fractures. The top and bottom of lava flows, particularly where associated with palaeosoils, are often highly fractured and weathered; towards the middle of the lava flows, the basalt tends to be more competent and less fractured. Figure 4 shows aspects of groundwater flow in highland volcanic areas in Ethiopia. In southern Africa, large volumes of flood basalts erupted from centres in present day Lesotho, SE South Africa, Mozambique, western Zimbabwe and north-eastern Botswana. These thick extrusive sequences of basalts and ash deposits were associated with the intrusion of extensive dolerite ring and dyke swarm complexes within the present day regions of south-eastern South Africa, southern Zimbabwe and north eastern Botswana (TAMS, 1996; Woodford \& Chevallier, 2002). 


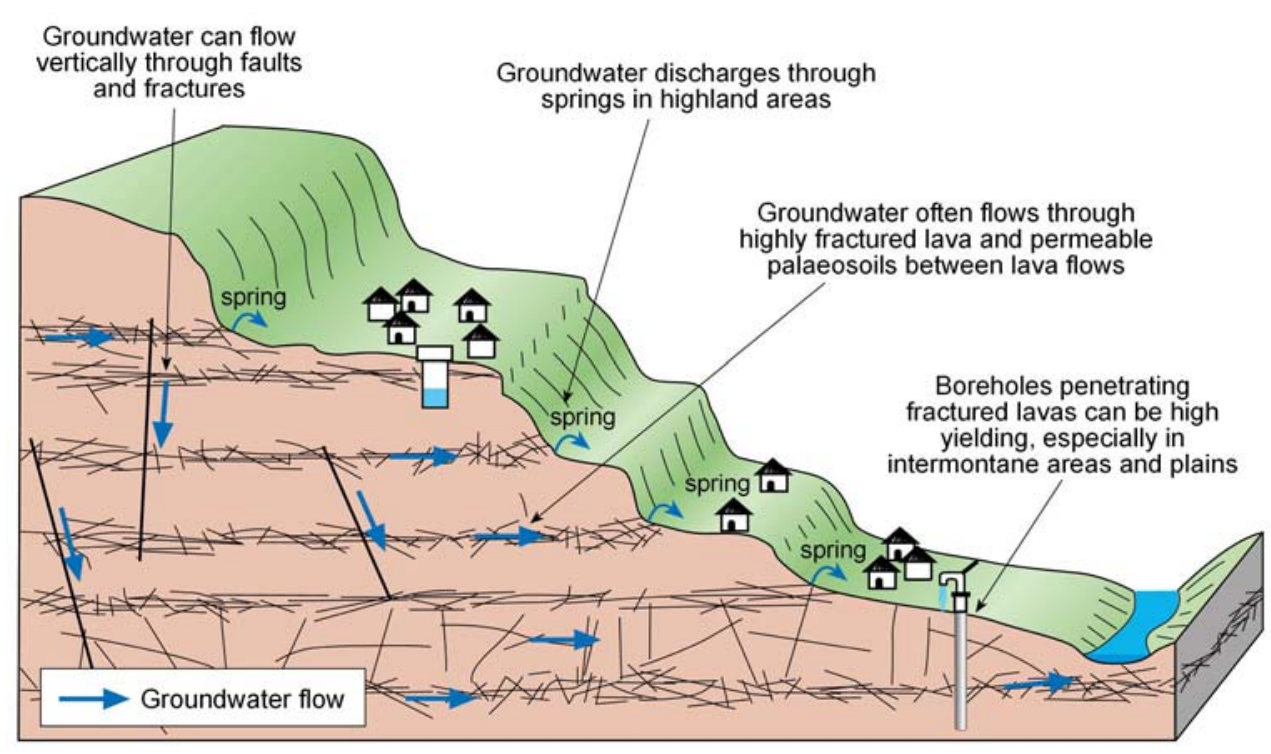

Figure 4 Groundwater occurrence in volcanic rocks.

The most important factors for the development of aquifers within volcanic rocks are given below (Kehinde \& Loenhert 1989; Vernier 1993):

- Thick palaeosoils or loose pyroclastic material between lava flows are often highly permeable;

- joints and fractures due to the rapid cooling of the tops of lava flows provide important flow pathways;

- contact between lava flows and sedimentary rocks or earlier volcanic material such as domes etc. are often highly fractured and contain much groundwater;

- gas bubbles within lava flows, and porosity within ashes and agglomerates can provide significant groundwater storage.

Fractured lava flows can have very high permeability, but yields exhibit large variations with average values from boreholes about 2 l/s (UNTCD, 1989), which is more than adequate for rural domestic water supplies. Boreholes are generally more suitable than hand dug wells, since the fracture zones with significant groundwater are often deep. However, in Kenya, where the volcanic rocks form vast tablelands, the groundwater can be shallow, and sometimes exploited by dug wells. Dug wells can also be used in mountainous areas, where aquifers are small and water-levels sometimes shallow. Springs are common in volcanic rocks, particularly in highland areas. The interconnected fractures and cavities found in the lava flows provide rapid discrete flow paths for groundwater, which often discharge as 
springs at impermeable boundaries. Springs, particularly at higher altitudes can be more susceptible to drought failure than boreholes (Calow et al., 2002).

The quality of groundwater can be a problem in volcanic rocks. Fluoride concentrations are sometimes elevated and concentrations in excess of $1.5 \mathrm{mg} / \mathrm{l}$ can lead to health problems such as dental or skeletal fluorosis. High fluoride groundwaters are common in the rift valley regions of Kenya and Tanzania (e.g. Ashley \& Burley, 1995; Reimann, 2003).

Geophysical techniques have sometimes been used in volcanic terrain to site boreholes, but few general guidelines have been developed. Remote sensing techniques may be valuable for detecting different geological units and identifying fracture zones but have not been widely applied. Boundaries between volcanic rocks and sedimentary rocks could be easily identified with magnetic methods. Resistivity methods have been used to locate vertical and horizontal fracture zones in East Africa (Drury et al., 2001). However locating deep horizontal fracture zones (such as the boundary between lava flows) can be difficult using geophysics, and boreholes may have to be drilled relying solely on experience from previous drilling in the area.

\section{Consolidated sedimentary rocks}

Consolidated sedimentary rocks occupy $32 \%$ of the land area of SSA (Figure 2). Approximately 135 million people live in rural areas underlain by these rocks. Sedimentary basins can store considerable volumes of groundwater, but in arid regions, much of the groundwater can be non-renewable, having been recharged when the area received considerably more rainfall. Also, sedimentary rocks are highly variable and can comprise low permeability mudstone and shale as well as more permeable sandstones and limestones Examples of large sedimentary basins in sub-Saharan Africa (Figure 5) are the Karoo (tillite, mudstone, sandstone and conglomerate), and Kalahari Basin sediments (mudstone and sandstone with uncompressed cover sediments of poorly consolidated muds, silts and sands with associated consolidated evaporate sediments such as calcrete and silcrete) of Southern and Central Africa (Truswell, 1970), sediments within the Somali basin of East Africa and the Benue Trough of West Africa (Selley, 1997). 


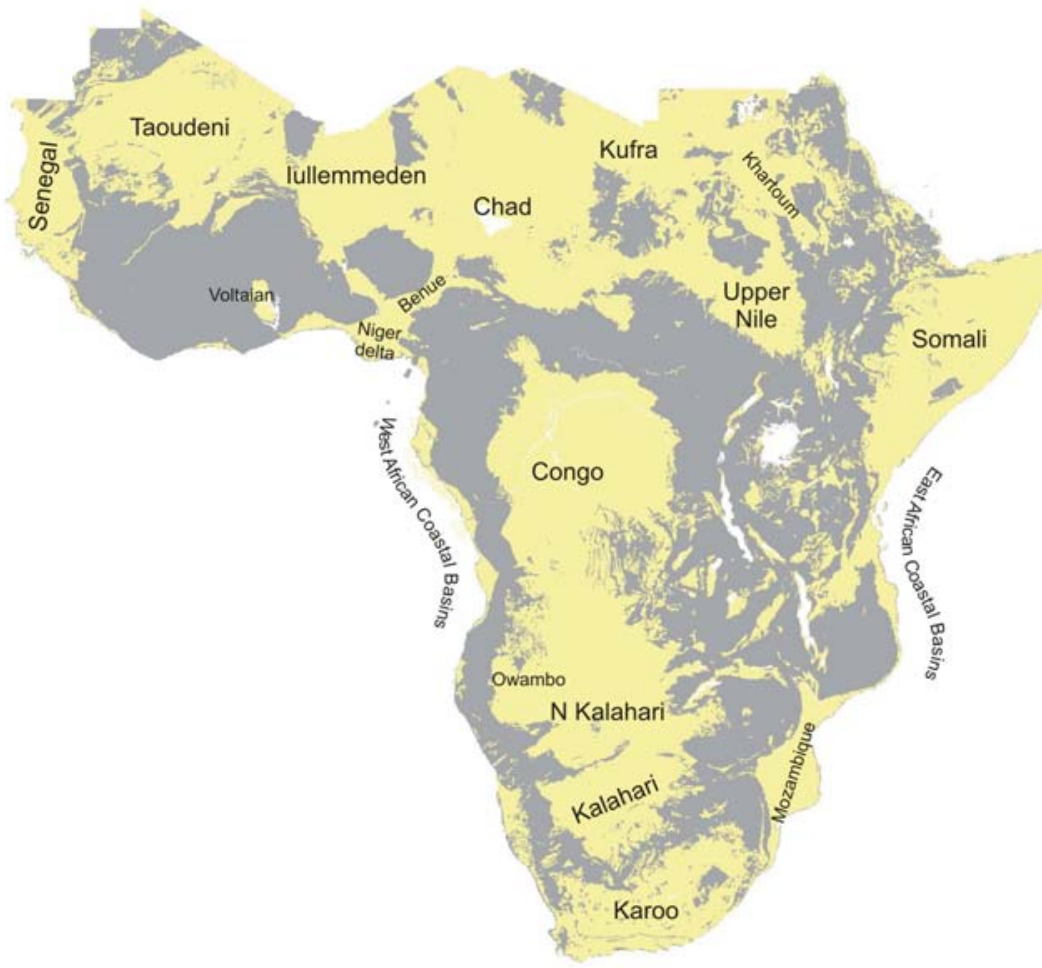

Figure 5. The location of large sedimentary basins in sub-Saharan Africa.

For the purposes of creating the simplified map shown in Figure 2, sedimentary rocks deposited before Quaternary times are assumed to be mainly consolidated. Figure 6 illustrates how groundwater occurs in consolidated sedimentary rocks.

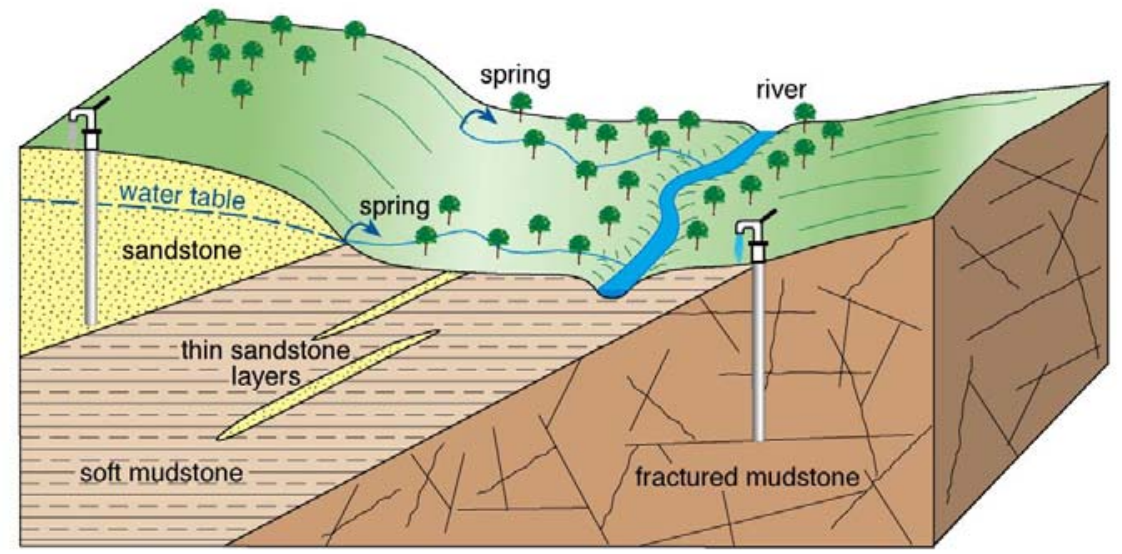

Figure 6. A schematic diagram illustrating how groundwater for rural water supply can exist within sedimentary rocks.

Consolidated sandstone and limestone contain significant groundwater. Shallow limestone aquifers are often vulnerable to saline intrusion and pollution (e.g. the limestone aquifers 
along the East African coast). Carefully constructed deep boreholes into thick sandstone aquifers can provide high yields (e.g. Middle and Upper Karoo sandstones of South Africa, Botswana and western Zimbabwe (Interconsult, 1985; Woodford \& Chevallier, 2002; Cheney et al., 2006). Yields are highest where the sandstones are weakly cemented or fractured. This makes the aquifers highly suited to large-scale development for reticulated urban supply, industrial uses and agricultural irrigation. However, rural water supply generally relies on shallow boreholes or wells close to communities. Only rocks immediately surrounding the community and to a depth of less than $100 \mathrm{~m}$ are usually considered. In large sedimentary basins, where modern recharge is limited, water-levels can be deeper than $50 \mathrm{~m}$, and therefore difficult to abstract using a handpump. More sophisticated approaches may be required for rural water supply in such areas requiring deeper boreholes, header tanks and distribution systems.

Although mudstone and siltstone are poor aquifers, groundwater can often be found in these environments with careful exploration. Studies in Nigeria showed that where mudstone is soft and dominated by smectite, negligible groundwater exists; in slightly metamorphosed mudstone, where the rocks have been altered to become harder, fractures can remain open and usable groundwater can be found (MacDonald et al., 2005). Similar problems have been encountered in the fine grained aeolian and fluvially deposited Karoo age sediments (as in south Africa and Lesotho (Sami, 1996)). It is estimated that $65 \%$ of all sediments are mudstone (Aplin et al., 1999); therefore, up to 75 million people may live directly on these mudstone areas. Figure 7 illustrate how groundwater exists in mudstone areas. 


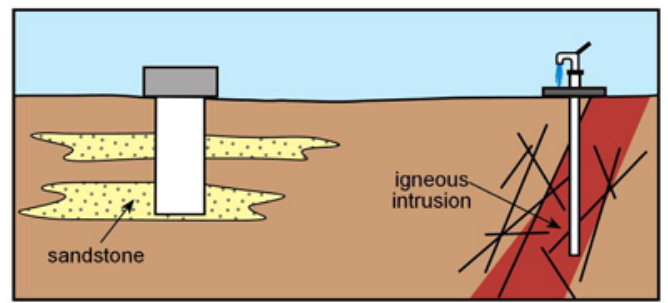

In smectite rich mudstones there

is no usable water within the

clay. The only water in these

areas is found in thin sandstone

layers or small igneous intrusions

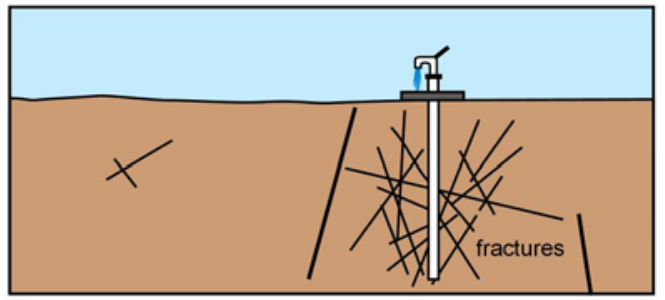

If the mudstone has been buried and altered to become slightly harder (mixed layer I/S clays), usable groundwater can be found in large fractures and faults. Faults and fractures however, may be far apart.

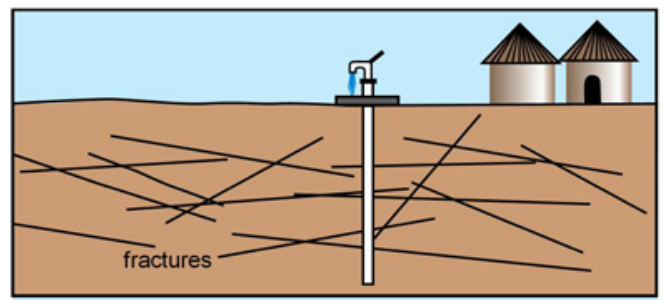

Where mudstones have been altered to comprise hard shales, fractures are widespread and groundwater is easily found.

Figure 7. Groundwater occurrence in mudstone areas (after MacDonald et al., 2005).

Geophysical techniques can be used to identify good aquifers. Sandstone can easily be distinguished from mudstone using ground conductivity or resistivity methods (e.g. Interconsult, 1985; Bromley et al., 1996 ). Similarly, harder mudstones can also be distinguished from soft mudstone (MacDonald et al., 2001). In areas where large sandstone or limestone aquifers are present, little or no detailed siting is required for rural domestic supply; boreholes can be drilled anywhere. Occasionally, if the aquifers and groundwater levels are shallow, dug wells can be constructed.

\section{Unconsolidated sediments}

Unconsolidated sediments form some of the most productive aquifers in Africa. They cover approximately $22 \%$ of the land surface of SSA (Figure 2). However, this is probably an underestimate of their true importance since only the thickest and most extensive deposits are shown on the map. Unconsolidated sediments are also present in many river valleys throughout Africa. Examples of extensive deposits of unconsolidated sediments are found in Chad, Congo and Mozambique (the amalgamated deltas of the Save, Zambezi and the 
Limpopo) and in the coastal areas of Nigeria (Niger Delta), Ghana, Somalia, Namibia, Madagascar and Kenya. There is no clear dividing line between unconsolidated sediments and consolidated sedimentary rocks, as the time taken for consolidation can vary. However, for most purposes it can be assumed that sediments deposited in the past few million years (during Quaternary and late Neogene times) will remain unconsolidated. Unconsolidated Sedimentary Aquifers are often described as UNSAs.

Unconsolidated sediments comprise a range of material, from coarse gravel and sand to silt and clay. They are deposited in different environments such as rivers and deltas by various combinations of physical processes. Large unconsolidated sedimentary basins can store large amounts of groundwater. Guiraud (1988) describes several of the major UNSAs in Africa. As with consolidated sedimentary rocks, where the basins are now in arid regions, the water they contain may not be currently renewable. The size and physical characteristics of the aquifer depend on how the sediment was deposited. Sand and gravel beds can be continuous over hundreds of kilometres, but are often multi-layered, with sands and gravels interbedded with silts and clays. Depending on the depositional environment, the structure of the aquifers can be highly complex, with sediments changing laterally within a few metres (see Figure 8).

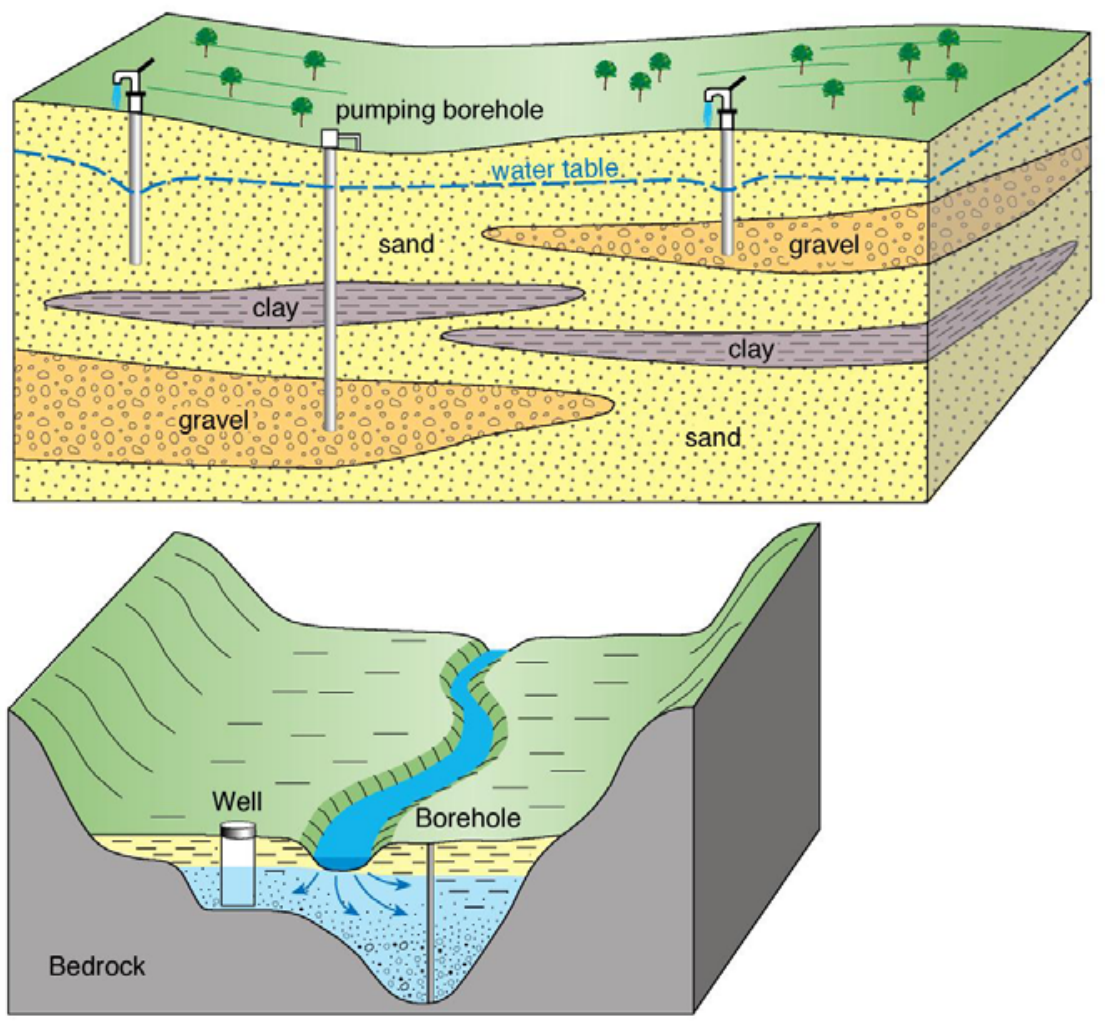

Figure 8 Groundwater occurrence in large unconsolidated sedimentary basins (top) and small unconsolidated valley deposits (bottom). 
Small UNSAs are found throughout SSA. On basement, volcanic and consolidated sedimentary rocks, UNSAs can be found in valleys, deposited by present day rivers. Here, groundwater is close to the surface, so pumping lifts are small; also the proximity to the rivers offers a reliable source of recharge. In southern Africa, sand-rivers are important sources of water for domestic and stock watering use. Research into the occurrence of groundwater in sand rivers has been undertaken in Botswana (e.g. Wikner, 1980; Herbert et al., 1997; Davies et al., 1998), Namibia (Jacobson, et al., 1995), South Africa (Clanahan \& Jonch, 2005) and Zimbabwe (Owen, 1989). These rivers rarely contain surface water, but the thick sediment within the river channel can contain significant groundwater. In northern Nigeria, shallow floodplains known as fadamas, are important sources of groundwater (Carter \& Alkali, 1996). These floodplains may be several kilometres wide and can contain $10 \mathrm{~m}$ of sands and gravels. They rely on annual flooding for recharge.

Where the structure of UNSAs is complex, geophysical techniques can be used to distinguish sand and gravel from clay. Ground penetrating radar, shallow conductivity and resistivity surveys are all routinely used in groundwater exploration in UNSAs. Ekstrom et al. (1996) describe the application of resistivity to find groundwater in river alluvium in SW Zimbabwe; Davies et al. (1998) used shallow seismic refraction to investigate sand rivers in NE Botswana and MacDonald et al. (2000) describe the use of ground conductivity and ground penetrating radar for locating groundwater in alluvium and blown sands. Remote sensing techniques such as satellite imagery and aerial photography can also be used to provide information on the distribution of sedimentary systems.

UNSAs are easy to dig and drill, so exploration is rapid and inexpensive. Where groundwater is shallow, simple hand drilling is often effective. Where boreholes have to be deeper, drilling can be more problematic. Groundwater quality problems can occur in UNSAs due to natural geochemistry and contamination. Problems can arise where groundwater is developed from such sediments with little regard to the water chemistry. High arsenic concentrations in groundwater within Bangladesh and India were undetected until the local population developed symptoms of arsenic poisoning (Kinniburgh et al., 2003). 


\section{Discussion: using appropriate groundwater knowledge}

The premise of this paper is that knowledge of groundwater resources and hydrogeological expertise is fundamental to successful and sustainable rural water supplies. The technical capacity required to develop groundwater resources differs with the hydrogeology: in some environments little expertise is required, while in others considerable research and money is required to develop groundwater. In this discussion we highlight four areas where hydrogeological expertise can be focussed to maximise the benefit to rural water supplies. (1) existing knowledge transfer; (2) benchmarking; (3) researching difficult areas; and (4) providing accessible advice to planners and policy makers

\section{Knowledge Transfer}

Implementers of rural water supply programmes (those tasked with siting water points, designing boreholes/wells, assessing yield, quality and sustainability) form a varied group with a wide range of skills and disciplines. They may be water engineers, geologists, geophysicists, hydrogeologists or general technicians. Trained and experienced groundwater specialists are rare. Therefore, there is a pressing need for groundwater development skills to be made more widely available within rural water supply projects. This could be achieved in a number of ways:

1. Developing manuals designed specifically for the issues surrounding rural water supply (e.g. MacDonald et al., 2005).

2. Producing groundwater development maps that indicate the availability of groundwater resources, and the techniques required to find and develop groundwater in different areas.

3. Running regular incountry training courses and workshops, where the useful skills can be developed and lessons shared from different projects

4. Creating local, regional and worldwide networks to provide a pyramid of support to the project staff undertaking the work.

5. Investing research into developing new simple but effective techniques for use by project staff on rural water supply.

To be able to transfer knowledge, that knowledge first needs to be available. However, decentralisation and the promotion of demand-responsive approaches to service provision 
have had significant implications for building knowledge of groundwater in Africa. In particular, local institutions - including local government and NGOs. While this move has many benefits and promises greater sustainability, decentralisation has been to the detriment of national databases, national knowledge and control over borehole drilling and construction standards. As a consequence, knowledge of groundwater resources is not growing or even being maintained in much of SSA. This new reality will need to be embraced and new methods and possibly institutions developed to ensure that data is captured from ongoing projects and transformed to information which can be assimulated as knowledge by those who need it.

\section{Benchmarking}

As the provision of rural water supply becomes increasingly decentralised, budget holders (who are often based in district or local government) have little knowledge about the complexities of hydrogeology and groundwater investigations. This makes it difficult for them to judge whether a drilling success rate is justified due to difficult terrain, or whether a project is over specified in easy terrain. Knowledge of local hydrogeology and the business of groundwater development is required to be able to make informed decisions about designing and managing projects.

Simple cost-benefit analysis can help if data are available on drilling costs and success rates 'with' and 'without' different levels of investigation. As noted in Farr et al. (1982) the use of a particular search technique is only justified if it increases the chances of subsequent boreholes being successful, such that the overall saving in drilling costs (through drilling fewer unsuccessful boreholes) is greater than the cost of the search. In some environments, where groundwater is readily available, expensive methods may not be justified. In other environments, however, seemingly expensive methods or studies may be entirely justified by long term savings in drilling costs.

Therefore, it is fundamental to the success of decentralised programmes that the local governments have sufficient hydrogeological expertise. Hydrogeologists can be of value in a number of ways:

1. Facilitating the acquisition of the knowledge and skills required by the decentralised bodies to manage contractors. This may be through the various methods described in the section on "knowledge transfer" above. 
2. Providing authoritative guidelines against which proposals, projects and contractors can be assessed. This "benchmarking" role is increasing in importance and visibility within the development community.

\section{Research in complex areas}

Areas where sustainable groundwater sources are hard to find often have the greatest problems with health and poverty. In these areas, women have to walk further to find water and waterborne diseases such as guinea worm are more common. Helping to solve water problems in these difficult areas may have greater impact on reducing poverty in sub-Saharan Africa than drilling many more boreholes in areas where it is relatively easy to find water.

By effectively disseminating techniques to project staff in areas where it is relatively easy to find groundwater, hydrogeological expertise and research budgets can focus on more difficult areas where groundwater occurrence is not well understood and rural water supplies rarely effective. Some issues that demand more research are:

- the age, recharge and sustainability of groundwater supplies in basement areas, particularly during drought; this will become increasingly important with a changing climate;

- the existence of groundwater in areas where groundwater is difficult to find (e.g. poorly weathered crystalline basement and mudstone areas), and developing techniques that can be used by project staff in these areas to find groundwater and develop rural water supplies;

- identify and understanding the constraints on rural water supply caused by natural groundwater contaminants, such as fluoride and arsenic;

- matching more closely technologies for accessing groundwater (wells, boreholes, springs, collector wells) with the hydrogeological environment and socio-economic conditions to maximise yield and sustainability, and minimise costs;

- examine the risks to rural water supply caused by the increase in onsite sanitation. 


\section{Informing policy}

Many of the current pillars of rural water supply policy stem from a change in thinking about the value of water and a recognition that centralised approaches to service delivery are unsustainable. A key objective of policies is the provision of potable water on a continuous basis: security of supply across seasons and between wet and dry years is essential if health and poverty alleviation benefits are to be met and sustained. Central pillars of modern policy include: treating water as a social and economic good; using demand responsive approaches which allows consumers to guide investment decisions; moving from community participation to community management; embedding rural water supply in larger initiatives which include sanitation and hygiene promotion; decentralizing service delivery; and recognising the broader livelihood benefits of rural water supply rather than concentrating only on public health.

These approaches have many benefits for improving rural water supply in Africa, however, they rely on informed decisions being made on technology choices and approaches. Unfortunately, this is rarely true. As discussed above, capacity rarely exists within projects to advise communities on the most appropriate approach to use in their particular community. Therefore, hydrogeologists have much to offer in influence how policies are translated into workable approaches on the ground. Only with determined interdisciplinary approaches will interventions be effective and sustainable.

\section{Conclusions}

Groundwater is central to helping sub-Saharan Africa meet the Millennium Development Goals for water supply. Rocks with poor aquifer properties ( $\mathrm{T} \sim 1 \mathrm{~m}^{2} / \mathrm{d}$ and $\mathrm{S} \sim 0.001$ ) will generally still support a village borehole with a handpump. The current approaches to rural water supply, in particular demand driven approaches, community participation and poverty focus have many benefits to the overall efficacy and sustainability of water supplies. However the underlying presumption that groundwater is ubiquitous, or can easily be found at each site is dangerous and my lead to many failures.

Crystalline basement occupies $40 \%$ of the land area of SSA; 235 million people live in rural areas underlain by crystalline basement rocks. Volcanic rocks occupy 6\% of the land area of SSA, and sustain a rural population of 45 million, many of whom live in the drought stricken 
areas of the Horn of Africa. Consolidated sedimentary rocks occupy 32\% of the land area of SSA and sustain a rural population of 110 million. Unconsolidated sediments occupy $22 \%$ of the land area of SSA and sustain a rural population of 60 million. They are probably more important than these statistics suggest since they are present in most river valleys throughout Africa.

Hydrogeologists have a key role in helping to meet the Millennium Development Goals, but must learn to work within the existing policy framework which gives social and economic factors a higher priority than groundwater resources. The four main areas of work for hydrogeologists are: 1) communicating techniques and knowledge to those responsible for siting and developing groundwater supplies; 2) benchmarking the expected expertise and quality for different hydrogeological environments; 3) researching complex areas, where little is known about groundwater resources; and 4) providing accessible and appropriate advice to policy makers. The hydrogeological community can help to reduce poverty in sub-Saharan Africa. The most pressing task is to communicate what we know to the people who need to know it.

\section{Acknowledgements}

This paper is published with the permission of the Executive Director of the BGS (NERC). Much of the work on which the paper is based was funded by the UK Department of International Development (DFID). The views expressed, however, are not necessarily those of DFID.

\section{References}

Aberra, T. 1990. The hydrogeology and water resources of the Ansokia highland springs, Ethiopia. Memoires of the $22^{\text {nd }}$ Congress of IAH, Vol XXII, Lausanne.

Acworth, R. I. 1987. The development of crystalline basement aquifers in a tropical Environment. Quarterly Journal of Engineering Geology, 20, 265-272.

Aplin, A. C., Fleet, A. J. \& MacQuaker, J. H. S. 1999. Muds and mudstones: physical and fluid flow properties. In: Aplin, A. C., Fleet, A. J. \& MacQuaker, J. H. S. (eds.) Muds and Mudstones: Physical and Fluid Flow Properties. Geological Society London Special Publications, 158, 1-8 . 
Ashley, R. P. \& Burley, M. J. 1995. Controls on the occurrence of fluoride in groundwater in the Rift valley of Ethiopia. In: Nash, H. \& McCall, G. J. H. (eds.) Groundwater Quality. Chapman \& Hall, London.

Ball, D. F. \& Herbert, R. 1992. The use and performance of collector wells within the regolith aquifer of Sri Lanka. Ground Water, 30, 683-689.

Beeson, S. \& Jones, C. R. C. 1988. The combined EMT/VES geophysical method for siting boreholes. Ground Water, 26, 54-63.

Bromley, J., Mannstrom, B., Nisca, D. \& Jamtlid, A. 1994. Airborne geophysics: Application to a ground-water study in Botswana. Ground Water, 32, 79-90.

Butterworth, J. A., Macdonald, D. M. J., Bromley, J., Simmonds, L. P., Lovell, C. J. \& Mugabe, F. 1999. Hydrological processes and water resources management in a dryland environment III: groundwater recharge and recession in a shallow weathered aquifer. Hydrology and Earth System Sciences, 3, 345-352.

Calow, R. C, MacDonald, A. M, Nicol, A. Robins, N. S. \& Kebede, S. 2002. The struggle for water: drought, water security and rural livelihoods. British Geological Survey Commissioned Report CR/02/226N.

Carruthers, R. M. \& Smith, I. F. 1992. The use of ground electrical methods for siting water supply boreholes in shallow crystalline basement terrains. In: Wright, E. P. \& Burgess, W. G. (eds.) The Hydrogeology of Crystalline Basement Aquifers in Africa. Geological Society London Special Publications, 66, 203-220.

Carter, R. C. \& Alkali, A. G. 1996. Shallow groundwater in the northeast arid zone of Nigeria. Quarterly Journal of Engineering Geology, 29, 341- 356.

Cheney, C. S., Rutter, H. K., Farr, J. \& Phofuetsile, P. 2006. Hydrogeological potential of the deep Ecca aquifer of the Kalahari, southwestern Botswana. Quarterly Journal of Engineering Geology and Hydrogeology, 39, 303 - 312.

Chilton, P. J. \& Foster, S. S. D. 1995. Hydrogeological characterisation and water-supply potential of basement aquifers in tropical Africa. Hydrogeology Journal, 3, 36-49.

Clanahan, M. J. \& Jonck, J. L. 2004. A critical evaluation of sand abstraction systems in Southern Africa. Water Research Commission of South Africa Report 829/3/05, Pretoria, RSA. 
Demlie, M., Wohnlich, S., Wisotzky. F. \& Gizaw, B. 2007 Groundwater recharge, flow and hydrogeochemical evolution in a complex volcanic aquifer system, central Ethiopia. Hydrogeology Journal, 15, 1169-1181

Davies, J., Rastall, P. \& Herbert, R. 1998. Final report on the application of collector well systems to sand rivers pilot project. British Geological Survey Technical Report WD/98/2C

DFID 2001. Addressing the water crisis: healthier and more productive lives for poor people. Department for International Development, London

Drury, S. A, Peart, R. J. \& Andrews Deller, M. E. 2001. Hydrogeological potential of major fractures in Eritrea. Journal of African Earth Sciences, 32, 163-177.

Edmunds, W. M. \& Gaye, C. B. 1994. Estimating the spatial variability of groundwater recharge in the Sahel using chloride. Journal of Hydrology, 156, 47-59.

Edmunds, W. M., Fellman, E. Goni, I. \& Prudhomme C. 2002. Spatial and temporal distribution of groundwater recharge in northern Nigeria. Hydrogeology Journal, 10, 205215.

Ekstrom, K., Prenning, C. \& Dladla, Z. 1996. Geophysical Investigation of Alluvial Aquifers in Zimbabwe. MSc Thesis. Department of Geotechnology, Institute of Technology, Lund University, Sweden.

ESRI 1996. ArcAtlas: Our Earth. Environmental Systems Research Institute, USA

Farr, J. L., Spray, P. R. \& Foster, S. S. D. 1982. Groundwater supply exploration in semi-arid regions for livestock extension - a technical and economic appraisal. Water Supply and Management, 6, 343-353.

Foster, S. S. D. 1984. African groundwater development - the challenges for hydrogeological science. Challenges in African Hydrology and Water Resources (Proceedings of the Harare symposium, July 1994), IAHS Publication 144.

Foster, S. S. D., Chilton, P. J., Moench, M., Cardy, F. \& Schiffler, M. 2000. Groundwater in rural development. World Bank Technical Paper 463, The World Bank, Washington DC.

Guiraud, R. 1988. L'hydrogeologie de l'Afrique. Journal of African Earth Sciences, 7, 519543. 
Herbert, R., Barker, J. A., Davies, J. \& Katai, O. T. 1997. Exploiting ground water from sand rivers in Botswana using collector wells. In: Fei Jin, Krothe, NC (eds) Proceedings of the 30th International Geological Congress China, 22, Hydrogeology, 235-257.

Hulme, M., Doherty, R., Ngara, T., New, M. \& Lister D. 2001. African climate change: 19002100. Climate Research, 17, 145-168.

Interconsult 1985. National Master Plan for Rural Water Supply and Sanitation. Volume 2/2 Hydrogeology. Ministry of Energy and Water Resources and Development, Republic of Zimbabwe.

Jacobson, P. J., Jacobson, K. M. \& Seely, M. K. 1995. Ephemeral rivers and their catchments: Sustaining people and development in Western Namibia. Desert Research Foundation of Namibia, Windhoek, 160pp.

Jones, M. J. 1985. The Weathered Zone Aquifers of the Basement Complex Areas of Africa. Quarterly Journal of Engineering Geology, 18, 35-46.

Kebede, S., Travi, Y., Asrat, A., Alemayehu, T. \& Tessema, Z. 2007. Groundwater origin and flow along selected transects in Ethiopian rift volcanic aquifers. Hydrogeology Journal, DOI: $10.1007 /$ s10040-007-0210-0.

Kehinde, M. O. \& Loehnert, E. P. 1989. Review of African groundwater resources. Journal of African Earth Sciences, 9, 179-185.

Key, R. M. 1992. An introduction to the crystalline basement of Africa. In: Wright E. P. \& Burgess, W. G. (eds.) The Hydrogeology of Crystalline Basement Aquifers in Africa. Geological Society London Special Publications, 66, 29-58.

Kinniburgh, D. G. , Smedley, P. L., Davies, J., Milne, C. J. , Gaus, I., Trafford, J. M., Burden, S., Huq, S. M. I., Ahmad, N. \& Ahmed, K. M. 2003. The scale and causes of the groundwater arsenic problem in Bangladesh. In: Welch, A. H. \& Stollenwerk, K. G. (eds.), Arsenic in Groundwater, Kluwer Academic Publishers, pp 211-257.

Kulkarni, H., Deolankar, S. B., Lalwani, A., Josep, B., Pawar, S. 2000. Hydrogeological framework of the Deccan basalt groundwater systems, west-central India. Hydrogeology Journal, 8, 368-378.

Lillesand, T. M. \& Kiefer, R. W. 1994. Remote Sensing and Image Interpretation ( $3^{\text {rd }}$ Edition). John Wiley \& Sons, New York. 
Lovell, C. 2000. Productive water points in dryland areas - guidelines on integrated planning for rural water supply. ITDG Publishing, Rugby, UK.

MacDonald, A. M, Ball, D. F. \& McCann, D. M. 2000. Groundwater exploration in rural Scotland using geophysical techniques. In: Robins, N. S. \& Misstear, B. D. R. (eds.) Groundwater in the Celtic Regions: studies in hard rock and Quaternary Hydrogeology. Geological Society London Special Publications, 182, 205-217.

MacDonald, A. M. \& Davies, J. 2000. A brief review of groundwater for rural water supply in sub-Saharan Africa. British Geological Survey Technical Report WC/00/33.

MacDonald, A. M., Davies, J. \& Peart, R. J. 2001. Geophysical methods for locating groundwater in low permeability sedimentary rocks: examples from southeast Nigeria. Journal of African Earth Sciences, 32, 115-131.

MacDonald, A., Davies, J., Calow, R. \& Chilton, J. 2005. Developing groundwater: a guide for rural water supply. ITDG Publishing, Rugby, UK, 358 pp.

MacDonald A. M., Barker, J. A. \& Davies, J. 2008. The bailer test: a simple effective pumping test for assessing borehole success. Hydrogeology Journal,

Macdonald, D. M. J., Thompson, D. M. \& Herbert, R. 1995. Sustainability of yield from wells and boreholes in crystalline basement aquifers. British Geological Survey Technical Report WC/95/50.

Simms, A., Magrath, J. \& Reid, H. 2004. Africa: up in Smoke? Oxfam, UK.

McNeill, J. D. 1991. Advances in electromagnetic methods for groundwater studies. Geoexploration, 27, 65-80.

Milsom, J. 2002. Field geophysics, $3^{\text {rd }}$ Edition. John Wiley and Sons Ltd, London.

New, M. \& Hulme, M. 1997. A monthly rainfall dataset for Africa for 1951 to 1995. IPCC. University of east Anglia.

Owen, R. J. S. 1989. The use of shallow alluvial aquifers for small scale irrigation; with reference to Zimbabwe. Final report of ODA Project R4239. University of Zimbabwe and Southampton University, UK. 
Persits, F., Ahlbrandt, T., Tuttle, M. Charpientier, R., Brownfield, M. \& Takahashi, K. 1997. Maps showing geology, oil and gas fields and geological provinces of Africa. USGS Openfile report 97-470A.

Reimann, C., Bjorvatn, K., Frengstad, B., Melaku, Z., Tekle-Haimanot, R., \& Siewers, U. 2003. Drinking water quality in the Ethiopian section of the East African Rift Valley I - data and health aspects. Science of the Total Environment, 311, 65-80.

Robins, N. S., Davies, J., Farr, J. L. \& Calow, R. C. 2006. The changing role of hydrogeology in semi-arid southern and eastern Africa. Hydrogeology Journal, 14, 1483-1492.

Sami, K., 1996. Evaluation of the variations in borehole yield from a fractured Karoo aquifer, south Africa. Ground Water, 34, 114-120.

Selley, R. C. 1997. African Basins. Sedimentary Basins of the World 3 (Series editor: K. J. Hsu) Elsevier, Amsterdam.

TAMS 1996. Water Resources Management: Policy and Strategies, Final Report. Department of Water Affairs, Ministry of Natural Resources, Lesotho. (2.4.24), Section 1, Part 4 Groundwater Resources.

Taylor, R. G., Howard, K. 2000. A tectono-geomorphic model of the hydrogeology of deeply weathered crystalline rock: Evidence from Uganda. Hydrogeology Journal, 8, 279-294.

Truswell, J. F. 1970. An introduction to the historical geology of South Africa. Purnell, Cape Town, RSA.

UNESCO 1991. Africa Geological Map Scale (1:5,000,000). 6 Sheets. UNESCO, Paris.

United Nations 2000. United Nations Millennium Declaration. United Nations General Assembly, A/RES/55/2. United Nations. New York.

UNTCD 1988. Groundwater in North and West Africa. Natural Resources/Water Series, 18, United Nations.

UNTCD 1989. Groundwater in Eastern, Central and Southern Africa. Natural Resources/Water Series, 19, United Nations.

Vernier, A. 1993. Aspects of Ethiopian Hydrogeology. In: Geology and mineral resources of Somalia and surrounding regions, Ist Agron. Oltremare, Firenze, Relaz e Monogr. 113, 687698. 
JMP 2004. Global water supply and sanitation 2004 report. Joint monitoring programme WHO/UNICEF, World Health Organisation, Geneva.

Wikner, T. 1980. Sand rivers of Botswana. Results from phase 1 of the Sand Rivers Project sponsored by the Swedish International Development Authority (SIDA).

Woodford, A. C. \& Chevallier, L. 2002. Regional characterisation and mapping of Karoo fractured aquifer systems - an integrated approach using geographical information system and digital image. Water Research Commission report 653/1/02, 192 pp.

World Bank, 2000. African development Indicators 2000. World Bank, Washington DC.

Wright, E. P. 1992. The hydrogeology of crystalline basement aquifers in Africa. In: Wright E. P. \& Burgess, W. G. (eds.) The hydrogeology of crystalline basement aquifers in Africa. Geological Society London Special Publications, 66, 1-27. 